\title{
Os indo-europeus antes e depois de Colin Renfrew
}

\section{Sobre RENFREW, Colin. L'énigme indo-euro-} péenne. Archéologie et Langage. Paris:

Flammarion, 1990.

Há livros que, com início modesto e por vezes até obscuro, pela segurança de sua ciência, por uma intuição genial ou pela sua novidade metodológica, com o passar do tempo adquirem grande importância no seu dominio de estudo. Outros, ao contrário, nascem sob a luz dos refletores, provocam enorme polêmica, e saem rápida e definitivamente de cena. Temo que seja este último o destino do livro do professor Renfrew.

O livro, que foi publicado em Londres, em 1987, por Jonathan Cape Ltd, é de uma enorme ambição. A julgar por seu argumento, alegremente aceito por alguns estudiosos da antiguidade, os estudos indo-europeus passariam a se dividir em a.C. e d.C. (antes e depois de Colin R.). Vejamos então a situação a.C.

1. Já faz mais de um século que os lingüistas identificaram, por estudos de léxico e gramática, a existência de ligações entre um grande número de línguas, dispersas num território vastíssimo. Quase todas as línguas européias, algumas da Ásia Central, e tão longe quanto a Índia. As semelhanças são por vezes tão flagrantes que não se podem explicar pelo acaso. Ora, estas línguas só são conhecidas por textos muito mais recentes (alguns da Idade Média), o que tornou necessário um trabalho imenso e muito dificil de lingüística retrospectiva ou regressiva para identificar as primeiras etapas da evolução e diferenciação lingüística. Houve um indo-europeu primordial que deu origem às línguas indo-européias (seguindo o modelo do latim com as neo-latinas)? Ou já havia na origem uma significativa diferenciação, que se acentuou com as migrações?

2. Migrações. Aqui entra o segundo capítulo desta história. A arqueologia conseguiu estabelecer que entre 3500 e 3000 a.C. (de Cristo, no caso) os nômades indo-europeus, partindo das estepes russas ou da Ásia Menor, invadiram toda a Europa, caminharam em direção ao Oriente até a Índia etc.

3. Do cruzamento entre a lingüística e a arqueologia muito foi explicado sobre a vida dos primeiros indo-europeus. Estrutura fortemente patriarcal, grande importância do pastoreio, metalurgia que ainda não trabalha o ferro etc.

Foram estas as etapas da pesquisa até meados do século XX, e elas geraram uma imensa bibliografia. São caminhos que não deixaram de ser trilhados desde então, por exemplo, por Émile Benveniste (Le vocabulaire des institutions indo-européennes. $\mathrm{Pa}$ ris: de Minuit, 1969, 2 v.) ou por P. BoschGimpera (Les indo-européens. Paris: Payot, 1961) e M. Gimbutas.

4. Estudando as mitologias presentes nos textos arcaicos de alguns povos de origem indo-européia, Georges Dumézil descobriu que o aparente caos das historietas divinas é só aparente, e que na verdade há uma grande consistência e homologia de estrutura no panteão de povos que não tiveram nenhum contato histórico após a dispersão indo-européia. É o que ele chamou a "tripartição funcional", com as hoje conhecidas funções da soberānia, guerra e produção (fecundidade, fertilidade). Duas questões se destacam aqui: a primeira foi a dificuldade, 
já ressaltada por Dumézil, de qualquer passagem rápida do nível de análise ideológico para a análise social (em termos de sociedades tripartidas em sacerdotes, guerreiros e camponeses). A razão é óbvia: este tipo de trabalho já é muito difícil para sociedades muito bem conhecidas e onde há abundância documental; quanto mais para os distantes indo-europeus! Mas a tentação é muito grande, evidentemente, e outros (embora não Dumézil) trabalharam neste sentido.

A segunda questão é a da continuidade ou não da estrutura trifuncional na e até a Europa medieval. Esta questão gerou um debate fascinante com outro Georges, Duby, que em vários trabalhos (e especialmente em Les trois ordres ou l'imaginaire du féodalisme. Paris: Gallimard, 1978) explica a trifuncionalidade medieval. Num colóquio especialmente dedicado à questão, Dumézil tendia a explicar a semelhança pela continuidade, Duby a partir de uma recriação especifica às condições do século XII.

Esta é a situação a.C. (Colin R.). Trata-se, no caso indo-europeu, de um domínio de estudos delicado, pois os fatos analisados se perdem na proto-história, e difícil, pois envolve a arqueologia de civilizações muito distantes e o conhecimento de línguas que, depois, se diferenciaram muito. Ora, para fazer uma necessariamente delicada intervenção de micro-cirurgia, o Dr. Renfrew muniu-se de uma moto-serra!

No seu furor iconoclasta, Colin Renfrew se aplica a demolir todas as hipóteses arqueológicas, lingüisticas e mitológicas existentes. Como ele é brilhante no seu ceticismo, não é dificil para este eminente arqueólogo de Cambridge mostrar as falhas nas teorias em vigor. A sua crítica dos modelos difusionistas por fluxo migratório é muito sólida e a sua explicação do sucesso das sepulturas com gobelets a partir das idéias da arqueologia social parece um grande avanço. O problema é que ele confunde tudo no seu furor e pretende tudo abarcar na sua hybris intelectual. Os elos mais frágeis das explicações tradicionais e os resultados mais seguros da pesquisa são confundidos na sua crítica. O resultado é a perda de todos os parâmetros. $O$ leitor mais ingênuo, ao fim do seu livro, poderá ter ímpetos de jogar no lixo Bosch-Gimpera, Benveniste e Dumézil, além dos dicionários de indo-europeu ou 0 Chantraîne. A sua crítica é tão avassaladora que ao final não resta nada. Este era aparentemente o seu objetivo. Após o tremor de terra começa a era d.C. (depois de Colin R.). Com as construções anteriores por terra, ele pode edificar a sua teoria. Do que se trata?

Segundo Renfrew, os primeiros indoeuropeus não saíram das estepes russas entre 3500 e 3000 em direção à Europa e Ásia, mas foram "ondas de avanço" que aconteceram 3000 anos antes disso, com a descoberta da agricultura. Com o crescimento demográfico resultante, pequenos deslocamentos de mais ou menos $30 \mathrm{~km}$ estenderam sucessivamente o domínio indo-europeu. O ponto inicial teria sido a Anatólia, mas com uma primeira etapa, muito próxima no tempo do berço original, que seria a ocupação da Grécia, atingida por navegação através do Egeu.

Tendo recuado 3000 anos em relação à datação tradicional, ele ataca G. Dumézil. Sociedades camponesas em 6000 a.C. não podiam ser tão claramente estruturadas $\mathrm{e}$ hierarquizadas quanto imagina e defende $\mathrm{G}$. Dumézil. As semelhanças e convergências entre Roma, a Islândia e a Índia seriam então fortuitas e não o resultado de uma herança comum.

O problema com o livro de Renfrew é, na minha modesta opinião, uma defíciência de método. Toda hipótese científica tem de ser elaborada a partir de parâmetros confiáveis. A partir daí, a hipótese pode ser testada. Os parâmetros podem não ser corretos e, caso isso fique constatado, devem ser mudados. 
Na sua crítica das hipóteses tradicionais, ele vira e revira os argumentos de forma quase sofística, sem se preocupar com a confiabilidade dos parâmetros. Assim, após a sua passagem, não resta nada. Ele critica igualmente argumentos fracos (e muitos já abandonados) e fortes, em pé de igualdade, não separando o trigo do joio.

Isto fica patente na sua crítica a Dumézil. Etapa $\mathbf{n}^{\circ}$ 1: a dispersão inicial (neste ponto é até surpreendente constatar que ele ainda acredita na existência histórica dos indoeuropeus) se dá por volta de $6000 \mathrm{a}$ C. e não em 3500-3000 a.C. Etapa n ${ }^{\circ}$ 2: em 6000 a.C. as sociedades não poderiam ser tão estruturadas e hierarquizadas como supõe Dumézil. Etapa $n^{0} 3$ : os trabalhos de Dumézil têm, talvez, valor etnográfico particular a cada sociedade estudada, mas não valor teórico geral comparativo entre diversos grupos indo-europeus.

O problema é que o seu edifício é menos seguro do que os que ele pretende ter demolido. Senão vejamos. 1. Ele liga a difusão das línguas indo-européias de maneira linear à difusão da agricultura, de forma ainda mais simplista que a tese anterior; 2 . o que dizer desta etapa grega em -6000 dos indo-europeus? A palavra está com os arqueólogos da Grécia, mas o meu ceticismo aqui é total. Um grupo indo-europeu (luvitas?) antes dos gregos, talvez. Mas uma etapa global como ele propõe, e milhares de anos antes?... 3. Ele pratica o raciocínio circular que ele tanto critica em outros: -6000 é muito cedo para as sociedades hierarquizadas de Dumézil? Mas quem disse que a boa data é -6000 e não $-3500-3000$ ? Colin Renfrew e ninguém mais. $\mathrm{E}$ ainda: segundo Dumézil, o que é hierarquizado é a ideologia religiosa e não necessariamente a sociedade.

Os estudos indo-europeus foram (e têm sido) ao longo de um século um magnifico laboratório científico, onde a decantada inter-disciplinaridade foi de fato praticada por lingüistas, arqueólogos e historiadores da religião. Engenhosas soluções metodológicas foram propostas, discutidas e corrigidas. Rotular esta aventura intelectual como "raciocínio circular" e tentar derrubar tudo com uma penada mostra sutileza de um elefante numa loja de cristais. E para quê? Propor um sistema ainda mais simples e mecânico.

Infelizmente o autor, que é uma inteligência brilhante, foi aqui vítima de desmedido orgulho intelectual. Entre a.C. e d.C., antes e depois de Colin Renfrew, a situação da "questão indo-européia" é rigorosamente a mesma.

JOSÉ ANTONIO DABDAB TRABULSI

Departamento de História

Faculdade de Filosofia e Ciências Humanas Universidade Federal de Minas Gerais 